\title{
FEMININE IMAGES IN THE WRITINGS OF AMOS OZ
}

\section{Dvir Abramovich*}

This essay explores the portrayal of female protagonists in several novels and short stories by Israel's most celebrated author Amos Oz. Employing feminist theory, the article argues that often in the Oz canon, the manner by which women characters are depicted can be read as antifeminist and misogynous. By embracing an oppositional reading which goes against the grain of conventional interpretation, the paper seeks to show that the adumbration of the female in an array of $\mathrm{Oz}$ texts is closely associated with a pervasive patriarchal praxis that focuses solely on their sexuality. The familiar image of the woman that is uncovered in this analysis demonstrates that in their multiple configurations, Oz's female principals are driven by libidinal impulses and that such characterization permeates the author's gender constructs. The article contends that $\mathrm{Oz}$ underlines in many of his plots the erotic dimension so much so that it becomes the mainstay for the heroines' actions and behaviour.

In the introduction to The New Feminist Criticism (1985) we read: 'Whether concerned with the literary representation of sexual difference, with the ways that literary genres have been shaped by masculine or feminine values... feminist criticism has established gender as a fundamental category of literary analysis. ${ }^{1}$ Intriguingly and lamentably, however, the fiction of Israel's greatest living author and two time Nobel Prize nominee Amos $\mathrm{Oz}$, has been relatively speaking shielded from the piercing eye of feminist discussion and excluded from the ongoing dialogue between literature and gender hermeneutics. Despite the critical surfeit regarding his letters which normally zeroes in on the political and social dimensions of his writings, feminist reappraisal of Oz's canon is still in its embryonic stage.

\footnotetext{
* Director and Jan Randa Senior Lecturer in Hebrew-Jewish Studies, Centre for Jewish History and Culture, The University of Melbourne. Email dvir@unimelb.edu.au

${ }^{1}$ Elaine Showalter, The New Feminist Criticism: Essays on Women, Literature and Theory (New York: Pantheon Books, 1985), 3.
} 
[2]This article has been informed by a methodological thematic feminist approach to re-examine several of the Amos $\mathrm{Oz}$ texts. At heart, the locus of this examination has been to re-evaluate the author's narratives through Feminist lenses, to predominantly re-enter its fictional dimensions and strategies with the particular objective aim of uncovering misogynous presumptions and distorted images of women. In the questions raised herein we have attempted to deconstruct patriarchal ideologies and their commensurate forms of ideas, values and syntax that for so long have served to transfer cultural and social antifeminist representations of women into textual discourse. It should be noted that a separate essay evaluating Oz's depiction of the mother figure - a key topos in his corpus - is forthcoming.

Our primary concern in this essay is to become a 'resisting reader', thereby adopting an oppositional reading stance which on the one hand encourages interpretation against the grain of fabricated truisms, and, on the other, inevitably leads to the exposition of deforming stereotypes and oppressing misrepresentations that permeate the author's constructions of female characters. In other words, we have engaged in unveiling the beliefs and implicit assumptions that determine the delineation of the female, as well as the underlying premises that disturbingly identify womanliness with an array of sexist attitudes that offensively degrade its female psyche and sexuality.

The main inspiration for this pure content and form investigation has been the pivotal literary analysis that originated with Simone de Beauvoir and Kate Milett, critics who saw literature as reflective of collective subjugating male fantasies. As a result, the structure and philosophical agenda of the essay is dominated by the theory of gender binarism and imagery myths, its underpinnings first stated by De Beauvoir in her treatise The Second Sex (1949), and eloquently summed up by Pam Morris:

De Beauvoir points out that a concept of 'otherness' is necessary for organizing human thought. We can acquire a sense of self - of 'me' - only in opposition to what is 'not me' - what is other... [and] 'woman' functions as the other in the same way which allows men to construct a positive self-identity as masculine. 
[3] And because what is other does not have identity in its own right, it often acts as an empty space to be ascribed whatever meanings the dominant group chooses. Thus women are frail not strong, emotional not rational, yielding not virile, so that masculinity can be defined as those positive qualities... by seeing women as other to themselves, as not-men, men can read into 'femininity' whatever qualities are needed to construct their sense of the masculine. So, a mythicised 'Woman' becomes the imaginary location of male dreams, idealizations and fears. $^{2}$

In the ideologically masculist world of literature, the mainstay of gender polarities, and one of the most persistent cultural models to oppress women, has been the employment of the female form to function solely as a sexual object in male-oriented narratives. Of the panoply of misogynous myths to occupy the site of fiction, the myth that equates femininity with sexuality, and which declaims that women are promiscuous, morally lax and lascivious is the most central to feminist issues of representation.

To put it differently, the social construction of gender is still driven by a patriarchal conceptual apparatus which articulates androcentric stereotypes in the portrayal of female protagonists. Thus, female characters are infantilised and devalued, as well as distinguished from men, by having their entire being generically defined purely in the sexual realm. Greer underscores the importance of this phenomenon when she writes 'The universal sway of the feminine stereotype is the single most important factor in male and female woman-hatred.' ${ }^{3}$

The claim being made here is that in Amos Oz's writings, the female characters, in their various permutations, tend to be subsumed and driven by their libidinal needs, to the extent that their whole being is propelled by the desire for sexual activity. Writing in 1976, critic Mordechai Avishay pointed to Oz's penchant in adumbrating his women protagonists as people who are ruled and controlled by their sexual yearning and are innately lustful: 'Oz emphasises in all of his stories the erotic element so much so that in some cases it becomes the main reason for their actions and

\footnotetext{
${ }^{2}$ Pam Morris, Literature and Feminism (Oxford: Blackwell Publishers, 1993), 14.

${ }^{3}$ Germaine Greer, The Female Eunuch (London: Macgibbon \& Kee, 1970), 261.
} 
[4]determines the internal content of the situations in the narratives... the meaning here is not of love, as real love does not exist here; and not an healthy eroticism, but one that has much of the sick and perverse. ${ }^{, 4}$ In alliance with Avishay, though not commenting on Oz's work, Hays shrewdly argues that the sex-coding of women operates on the 'smug assumption that a woman's biological difference sets her apart, that she is essentially inferior. ${ }^{5}$

Oz takes this point ne plus ultra in the novel To Know A Woman (1989) in which the character of Annamarie, the central hero's neighbour, is reduced and made to exist solely for the sexual pleasure and usefulness of the male protagonist, Yoel. Indeed, she is merely a presence in the book and not a veritable, three-dimensional protagonist. Thus, when she is initially introduced to the reader, it is only through Yoel's gaze on her body that we see her:

Annamarie... a petite, attractive woman, with childlike laughing blue eyes and cheeky pointed breasts. Hi she said cheerily when she noticed Yoel eyeing her body over the hedge... The woman came over to the hedge, her nipples squinting under a light cotton blouse. ${ }^{6}$

On his first visit to the home of Annamarie and her brother, Ralph, Yoel again experiences sensations of desire upon seeing her breasts, comparing them to those of an animal: 'In his mind he imagined his own wide, ugly hands, roughly clasping those breasts and putting an end to their convulsions, like catching warm chicks. ${ }^{7}$ Soon after, the brother leaves the room, as if by pre-arrangement with his sister, and Yoel and Annamarie make love. Consequently, Yoel, seeing that it is late, informs his hosts that it is time for bed, and takes his leave, urged by the two to visit again. From then onwards, a perverse ménage à trois forms: When Yoel wishes for sexual contact, he calls upon Annamarie and Ralph. After some superfluous talk and dinner, Ralph escorts Yoel to his sister's bed; Ralph, the voyeur, whom it is implied also sleeps with his sister, often stays to watch the two. What is one to make of these two scenes?

\footnotetext{
${ }^{4}$ Mordechai Avishay, 'Yetzarim Vetanim' [Jackals and Desires] Maariv (11 June 1976), 1-3.

${ }^{5}$ H.R Hays, The Dangerous Sex: The Myth of Feminine Evil (New York: Putnam, 1964), 17.

${ }^{6}$ Amos Oz, To Know A Woman (London: Vintage, 1992), 28-29. Hebrew original 1989.

${ }^{7}$ Ibid., 112.
} 
[5] [H]e allowed Ralph to take him to the bedroom. There, by the vague green underwater light, he saw Annamarie sleeping on her back like a baby, with her arms spread out by her sides and hair spread out on the pillow... Ralph began to undress him in a firm yet gentle way... unzipping his trousers, easing them down, pulling the underpants too, and then, with his arm round Yoel's shoulder like a swimming instructor leading a hesitant pupil to water, taking him to the bed and raising the blanket... covering the two of them, whispering good night and withdrawing. ${ }^{8}$

And:

[T] he overgrown farmer took Yoel's broad, ugly hands, which were brown like bread with garden soil under the fingernails, between his own pink abundantly freckled hands, and placed each of them slowly and gently on one of his sister's breasts, so accurately that Yoel could feel the stiffened nipple in the exact centre of his hand. Annamarie laughed softly. ${ }^{9}$

Earlier, Annamarie, infuriated by Yoel's treatment, asks whether he just sees her as a kitten. In the end, following Yoel's refusal to become anything more than a partner in bed, Annamarie ceases to be Yoel's sex toy, deciding to instead return to the United States. Later, Yoel wonders if it was so difficult to regard his 'mistress' with some respect, if it was impossible to merge erotic desire with consideration. It is noteworthy, that $\mathrm{Oz}$ has said that his purpose in writing the book was to present a man who attempts to discover and coexist in harmony with certain feminine elements within him, and to come to terms with the women who surround him. ${ }^{10}$ Nonetheless, one could argue that the portrayal of Annamarie betrays a completely different attitude.

Women's diminution to one of the sum of her parts and supposed sexual incontinence is dramatised in the encounter between the male protagonist Yonatan Lifshitz and [6]Michal, the soldier girl in A Perfect Peace (1982). ${ }^{11}$ On a personal odyssey through the desert, Yonatan, a Kibbutz member who has fled his marriage and home,

\footnotetext{
${ }^{8}$ Ibid., 188-189.

${ }^{9}$ Ibid., 228.

${ }^{10}$ Eleanor Wachtel, ‘Amos Oz’, Queens Quarterly 98:2 (Summer 1991), 429.

${ }^{11}$ Amos Oz, A Perfect Peace (London: Vintage, 1993). Hebrew original 1982.
} 
stumbles upon a military base, where he notices Michal. Immediately after she provides him with food and shelter, she relents to his superfluous advances and engages him in the most sensuous sex he has ever had. This chance tryst provides for three pages full of animalistic coupling (bordering on the pornographic) which for all their prosaic description and reflection of very common male fantasies, contain no psychological perspicuity about Michal nor the reasons she agrees to intercourse with this stranger. Clearly, she is an amalgam drawn from popular myths about the sybaritic nature of women. Later, the old man who provides guidance for Yonatan in the desert, compresses into a few sentences a woman's 'real worth':

Who was it? little Yvonne? Michal? Rafa'ella? Well, it's no business of mine. Between their legs they've all, heh, heh, got the same honeypot... You just happen to be down here and while away you are spending your nights shtupping Michal... As long as you get to the honeypot, bozhe moy, and have a stick to stir with it. Excellent! To fuck and live. ${ }^{12}$

In the same book, the two girls with whom Eitan, the Kibbutz member, lives, are only mentioned when Azariah, a fellow Kibbutz member, refers to them as whores, denoting their status in the tale as ornaments for the men. ${ }^{13}$ In another sequence Yonatan's wife, Rimona, whom Yonatan views as a frigid, placid mechanised doll is handed over to the newcomer Azariah by Yonathan, who moves into their house and into Rimona's bed; chattel-like, she sleeps with both men, ultimately impregnated by either one of the two. Importantly, this question is never resolved.

Indeed, it is of note that the issue of paternity appears elsewhere, underlying the facile notion that women are not to be trusted due to their sexual moral weakness. Examples of this include: Hava Lifshitz of A Perfect Peace and Ilana Brandsetter of Black Box [7] (1987), ${ }^{14}$ who both refuse, the former continuously, and the other initially, to disclose the identity of their child's father.

\footnotetext{
${ }^{12}$ Ibid., 327, 331.

${ }^{13}$ Ibid., 361 .

${ }^{14}$ Amos Oz, Black Box (London: Vintage, 1993). Hebrew original 1987.
} 
The projection of the female as object is also manifested in the delineation of the divorced wife of the nameless male protagonist of 'Tikkun Haolam' (Putting the World To Right, 1965). ${ }^{15}$ Although separated, and in spite of his hatred for her, he continues to visit her in the city as he still craves for the fruit of her body, knowing that she will oblige. At the end of the intercourse, she serves him coffee and he leaves. Towards the end of the story, when she informs him that she will no longer attend to his needs, as she is to be married, he departs angrily and picks up a city prostitute with whom he spends the night. Thus, unfortunately, it is a whore and an empty vessel in the shape of a kept-woman who represent femininity in the text.

The sexual marginalising of the female characters is also evident in Black Box. Boaz, ruler of his harem in Zikhron, dominates the gaggle of ethnically diverse girls whom he keeps for their labour and loin, and who grace the pages of the narrative to merely serve as inferior mistresses, but nothing more, 'Right now I'm with those two chicks, making them work and giving them a good time, eating, working a little, fucking...,16

The girls who frequent Ephraim's room in 'Mr Levi' (1976) ${ }^{17}$ are construed in a similar manner, evading the prying eyes of his father and Uri the child-narrator, selfappointed to guard his residence from the train of female worshippers. Furthermore, we are told that, while the other male characters - Uri and Mr Nehamkin - would succeed in fending off one admirer, the young women's persistent efforts would pay off and they would eventually manage to pierce his defence and satisfy their cravings by spending the night with Efraim.

Given that the novella is set in an historically vital period - the twilight of the British Mandate in 1940s Palestine and the preparation for the 1948 War of Independence, with almost all of the male characters invariably involved in the Underground or other [8]national matters, it is significant that the women are excluded from any public activity, occupying the plot's pages as simply distractions / attractions for the men, and are propelled by their physical needs. Thus Ruhama, whom Uri describes as lipless (and indeed she is silenced by the author), explains the indispensable urge she

\footnotetext{
${ }^{15}$ Amos Oz, 'Tikkun Haolam' [Putting the World to Right] in Artzot Hatan [The Lands of the Jackal] (Tel Aviv: Massada, 1965).

${ }^{16}$ Amos Oz, Black Box, 140.

17 Amos Oz, 'Mr Levi' in The Hill of Evil Counsel (London: Vintage, 1993). Hebrew original 1976.
} 
is naturally shackled to as a female: ‘[Y]ou don't understand anything. He does need it and how. Everybody does... You'll grow up yourself soon, and then you'll need it, too. You'll be dying for it. And then you won't be such a little hero.' ${ }^{18}$

Sure enough, the dark side of female sexuality is showcased in another novella, The Hill of Evil Counsel (1976) ${ }^{19}$ in the form of the two menacing baby-sitters, Madame Yabrova and Lybuov Binyamina. Taking advantage of the opportunity to give vent to their disturbed and abnormal sexual predilections when asked by the Kipnis family to watch Hillel, they lull the small boy into a false sense of security and molest him, deriving a sick pleasure from their sinister violation of his innocence:

Hands were pulling at his gym shorts. His organ which was taut like a thin pencil, was being touched with something like warm sticky jam... Then the slender pencil began to sneeze convulsively between the fingers of the musical women. The boy stifled a moan. Madame Yabrova let out a low, fleshy laugh. And Lyubov Binyamina suddenly panted like a dog. ${ }^{20}$

Another example of the phallocentric propaganda that subjugates and undermines women is the constant negative reference to their promiscuity and voracious erotic appetite, which is possibly the nastiest of the anti-feminist lexicon. From the outset, Ilana of Black Box is established as the scorned embodiment of this vilified stereotype. In her letters to her ex-husband, Alex, she vaunts of her adulterous exploits as the quintessential raving nymphomaniac, detailing her betrayals with his friends, army superiors, pupils, driver, the electrician and the plumber. ${ }^{21}$ In her own words a 'born harlot', ${ }^{22}$ she is also described, among other things, as a whore by her [9]son, ${ }^{23}$ Rahab by former husband Alex, ${ }^{24}$ and a dilapidated old car by his lawyer, Zakheim: 'It looks as though the gent is keeping her well serviced: she looks pretty good for her mileage, especially bearing in mind how many times she's changed hands. ${ }^{25}$ It is not

\footnotetext{
${ }^{18}$ Ibid., 96.

${ }^{19}$ Amos Oz, 'The Hill of Evil Counsel' in The Hill of Evil Counsel (London: Vintage, 1993). Hebrew original 1976.

${ }^{20}$ Ibid., 48-49.

${ }^{21}$ Amos Oz, Black Box, 42-44.

${ }^{22}$ Ibid., 41.

${ }^{23}$ Ibid., 2.

${ }^{24}$ Ibid., 89.

25 Ibid., 57.
} 
surprising that Goodman sums Ilana up as 'all id'. ${ }^{26}$ It is Alex, however, when explaining his doomed attraction to Ilana and women's overpowering sexual allure, who captures in a paragraph the essence of one of the book's themes:

You recognised an insect that was out of its mind at the smell of a female in heat. I didn't have a chance. You are stronger than I am, in the same ratio as the sun is stronger than snow. Have you ever heard of carnivorous plants? They are female plants that can exude a scent of sexual juices over a great distance, and the poor insect is drawn from miles away into the jaws that are going to close around it. It's all over Ilana. Checkmate. ${ }^{27}$ (my italics)

Later, Alex reformulates this misogynous equation, rolling into one utterance, a familiar, historically rooted misogynous discourse, 'You have the womb - you have the advantage. ${ }^{28}$ Literary scholar Yosef Oren finds that the common denominator linking Ilana and her son Boaz is their belief in the hedonistic ideal, especially Ilana, who preaches to her ex-husband Alex about utilising the present to pleasure the body, justifying her many episodes of infidelity.

Batya Pinski of 'A Hollow Stone' $(1965)^{29}$ is another illustration of an unchaste libertine who bestowed her sexual favours on a litany of men for reasons which the author never explains. After being widowed, we are told, she began to see Zeiger, a relationship viewed by the Kibbutz members with favour. Then, however, the situation unexpectedly deteriorated, as scoldingly reported by the narrator: 'Zeiger was the first, but he was not the last. Within a matter of weeks, news had spread of various peripheral characters finding their way to Batya Pinski's room at night. She [10]did not even turn her nose at refugees, or at eccentrics like Matityahu Damakov. ${ }^{30}$ Moreover, it is implied, that for this reason, her daughter Ditza, within a year or two, became a carbon copy of her mother, entertaining soldiers and visitors to the kibbutz, often running away to pioneering settlements and encampments in the desert.

\footnotetext{
${ }^{26}$ Ibid., 36.

${ }^{27}$ Ibid., 91.

${ }^{28}$ Ibid., 101 .

${ }^{29}$ Amos Oz, 'A Hollow Stone' in Where the Jackals Howl (London: Vintage, 1993). Hebrew original 1965.

${ }^{30}$ Ibid., 161.
} 
Bruria, the excessively wanton girlfriend of Itche, the deified commander of the short story 'The Trappist Monastery' $(1965)^{31}$ is explicitly locked into the confining parameters of a plot pattern that locates its umbilical motif as women's capricious sexual appetite. It shows Bruria having intercourse with two men on the same night, Nahum the medical orderly and Rosenthal the operations officer, while Itche is out on a reprisal mission. As the story begins we read of Itche's treatment of Bruria:

She would say 'You're disgusting, stop that', but these words always came from her lips warm and moist, as if she were really saying, 'More, more!' And he loved to insult her and even to humiliate her in the presence of the entire battalion... He used to scold Bruria, telling her to leave him alone, stop running after him all day, and come to him only at night... In the end she always came back to Itche, chastened, moaning and servile, almost begging for punishment. ${ }^{32}$

Since the narrative partly deals with an Israeli counter-raid in response to intense provocation from the Jordanian side - a quintessentially military situation - Oz could have provided some insight into the experience of a woman in this milieu, but interest instead turns to her virtues as a largely derogated stereotyped sexual creature. ${ }^{33}$ The enactment of the sex-scene between her and Nahum symbolises how the author subordinates content to archetype, 'She stretched out her hands to her sides as if awaiting crucifixion and said, "At least get it over with quickly." As it turned out, these words were not necessary. ${ }^{34}$ Later that night, Nahum finds Bruria, again, as a pathetically exploited figure, 'There he saw Bruria, leaning against the wall. The buttons of her blouse were open, one breast protruded from her brassiere, and [11]Rosenthal... was holding the nipple between two fingers... She stood there as if asleep on her feet or as if all was lost and there was no purpose left. ${ }^{35}$ Itche, on the other hand, is valorised in mythical and biblical terms by the narrator and fellow

\footnotetext{
${ }^{31}$ Amos Oz, 'The Trappist Monastery' in Where the Jackals Howl (London: Vintage, 1993). Hebrew original 1965.

32 Ibid., 89.

${ }^{33}$ Esther Fuchs, 'The Beast Within: Women in Amos Oz's Early Fiction', Modern Judaism 4:3 (1984), 317.

${ }^{34}$ Amos Oz, 'The Trappist Monastery', 96-97.

${ }^{35}$ Ibid., 98.
} 
soldiers, variously described as 'king, ${ }^{36}$ and 'spiritual brother of the warriors of King David. ${ }^{37}$ Tellingly, the nodal point of the plot revolves around a journey Nahum and Itche take to find Bruria, whom Itche falsely believes has left with another solider, namely, Rosenthal. In essence, Bruria serves as the catalyst for the character exploration of the two men that follows during the trip. The sense of locking the women into inferior and mainly sexual types make itself felt everywhere.

In the 1976 revised edition, the soldier girls' role in the preparation for the assault raid is restricted to providing the commando unit with cartons of sweets. ${ }^{38}$ At the same time, Itche mockingly reminds the girls not to forget to make ready 'lollipops on a stick' when the triumphant battalion returns. Elsewhere, the theme of women as sexual objects continues. We are told that Rosenthal, the operations officer would translate for Bruria the contents of pornographic magazines; Nahum, the medical orderly is caught cutting nude pictures of women and the general duty men would spend hours in the shower hut peeping through the holes they had punched in the partition between the men's and women's showers. As a whole, while the male characters are explored and eventually evolve, Bruria remains a thinly sketched prototypical patriarchal conception of a woman who is controlled by her anatomy and whose entire being connotes unbridled passion.

The fantasy-based image of the young, sometimes maiden, nubile and sexually immature girl who seduces older men is splendidly demonstrated in Where the Jackals Howl (1965) and Elsewhere Perhaps (1966). ${ }^{39}$ The fragmentation of persona is much emphasised in the introductory segment to the sixteen year old Galila in Where The Jackals Howl, where she is shown via a series of descriptions in the shower. It does disclose the author's disinterest in the character's intellect, and his preoccupation with her physiognomy. What follows next is Galila's visit to Matityahu [12]Damakov's room, an idiosyncratic loner, who is as old as her father or maybe older, to collect some canvasses and paint he promised her. Once in the room, Damakov reveals to Galila that he is her real father. The young siren, however, is undeterred by this sudden revelation, and dismisses his claim as untrue so as to enable

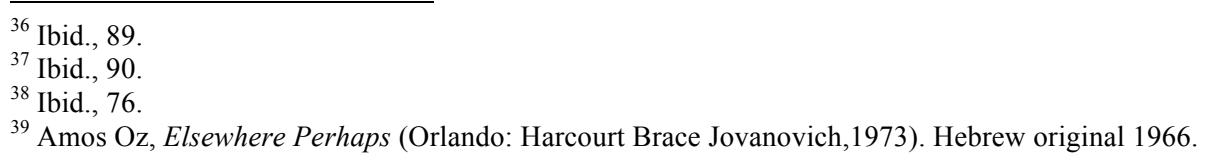


the consummation of their mutual and raging desire. Consequently, she urges him to give release to his wants, 'I'm not yours, I'm sure of it because I'm blond, I'm not yours or Leon's either, I'm blond and it's all right! Come on. ${ }^{40}$ The final bathetic sequence sees the two retreating from the copulation, intimating that Galila decides against this possible incestuous affair when she remembers her mother's face and is overcome by a pang of conscience.

It is in Elsewhere Perhaps that this theme is expanded and crystallised to take in the conquest of a middle-aged man by a virginal adolescent nymph, whom Miriam Arad has described as 'temptation incarnate'. ${ }^{41}$ The story fails to clarify why on the one hand the sixteen year old Noga rejects her teenage boyfriend, Rami, but on the other is drawn to the sweaty, hirsute middle-aged Ezra. In that context, the only clue to Noga's motives is a cryptic statement by her that Ezra's suffering has corrupted him, and that she must therefore purify him. The exploitative soft core sequence that details Noga's enticement of the older man (in the stable, no less) and the subsequent intercourse that takes place, overtly inverts the situation to present Noga as the wilful, experienced femme fatale, and Ezra as the naive, resisting victim:

Ezra took hold of her thin arm and tried to take her to her room. Noga wouldn't let him. She fought back. She stood rooted to the spot. Perplexed, he paused and looked at her, desperately tired... Noga clung to the man's powerful body. He tried to prize her loose. She gripped his clothes with her nails. Delicious kisses on his hairy, sweat-matted chest. Backward she dragged him step by tiny step into the thick darkness of the myrtle bushes. Who taught her tongue to lick his salty neck so tenderly? or her fingers to play so cleverly on the back of his neck... Her body awoke and filled with sweet gushes... Her breaths came in [13]pants, her mouth stretched wide open, her tiny teeth dug again and again into the blind flesh. ${ }^{42}$

It is significant that narratively, apart from the presence of the sexual objectification of women, the $\mathrm{Oz}$ diegesis is punctuated with scenes that contain physical and verbal

\footnotetext{
${ }^{40}$ Amos Oz, Where the Jackals Howl, 19.

${ }^{41}$ Miriam Arad, 'Devil in the Kibbutz', Jerusalem Post Book Reviews (28 October 1966), 21.

${ }^{42}$ Amos Oz, Elsewhere Perhaps, 127.
} 
violence against its female protagonists. Oz's stories heave with emotionally disturbing instances where permutations of violence are integrated as an ingrained literary strategy, stressing the acceptability of men's odious attitude towards the brutalisation of women's bodies. Ruthven explains why critics must not overlook this type of material: 'Male aggression against the female is capable of being displaced... into art forms, where it reproduces women as objects of sadistic humiliation. The persistent strain of misogyny in literature is therefore a matter of concern to anybody who views symbolic aggression as existing in the same continuum as acts of physical violence'. 43

Physical violence is very much in evidence in the novel A Perfect Peace. Yonathan's use of physical force against his wife, Rimona is manifested in several violent episodes which dramatise the seething anger towards Rimona accumulating inside of him. A striking evidence of this is proffered in the description of his endeavours to stimulate and arouse her frigid body, endeavours which involve a mix of tenderness and physical asperity:

The patient, bitter beating against her, the more and more desperate search everywhere for some opening, with kisses, with caresses, with cajolery, with silence, with cruelty... like a savage, like an ape, gently... obscenely, violently... his hands with sudden fury grasping, shaking her shoulders, shaking her back, her whole body, as if it were a watch that stopped ticking, even cuffing her face with the back of his hand, one time even with his fist. (my italics) ${ }^{44}$

Further, his rage is codified in the brutal imagery he chooses to express his sexual frustration and his yearning to shatter her torpid demeanour: 'Once and for all to grab [14] the bread knife and plunge it into her soft skin, into her vein and arteries, and down deeper yet, to open her up, to rampage through the dark lymph of her and the fat and the cartilage, to the innermost nooks and crannies, to the marrow of her bones, to carve her till she screamed. ${ }^{45}$ Disturbingly, the scenes of battery are reported in a non-judgmental, neutral manner, without being challenged either by the omniscient

\footnotetext{
${ }^{43}$ K.K. Ruthven, Feminist Literary Studies (Cambridge: Cambridge University Press, 1990), 83-84.

${ }^{44}$ Amos Oz, A Perfect Peace, 60-61.

${ }^{45}$ Ibid., 61-62.
} 
narrator or by the victim herself. This has the effect of alienating the reader from Rimona and leading him or her to either cast the blame on the heroine for submitting to the beating, or to assume that male violence against women is an acceptable part of marriage. Quite apart from Yonathan's deplorable actions, what is even more unsettling is that nowhere in the novel does Yonathan express a modicum of remorse or regret for his actions.

Black Box confirms and reinforces the male insanity that women respect and desire violence, that they are, as patriarchal codes of ideologies maintain, innately sadomasochistic. The novel taps a sexual machismo that articulates male prejudices about domestic violence and promotes the insidious retrograde fare about women's supposed masochistic nature. Milett sums up this entrenched common myth as: 'Masochism is female; femininity is masochistic. ${ }^{46} \mathrm{Oz}$ estranges the reader from the story's victim, Ilana Brandsetter, by intellectually eroticising the violence and by skirting along the edge of quintessential sexist discourse - he simply grounds his female character in morally defective Freudian and cultural conventions. Scutt explains these conventions: 'The Freudian concept of femininity, embodying an unconscious need for punishment and neurotic self-injury, is often used to explain domestic violence: why do women remain? because they love it, it is said. ${ }^{47}$ Susan Faludi found that the 80 s backlash saw a clamouring by the male psychiatric fraternity to re-introduce the quaint 'masochistic personality disorder' that classified Masochism as an inborn female trait. ${ }^{48}$

Formally, Black Box is structured as a series of stratagems to embed in the text the notion that Ilana, a battered wife, derived a sexual kick from the physical and verbal [15]humiliation dished out by her ex-husband Gideon. This is heightened by her reawakened yearning for his vituperative brand of abuse that permeates the fabric of the plot, and which explains her renewal of the relationship, seven years after its dissolution. As Goodman quite rightly points out: 'Ilana cannot do without her

\footnotetext{
${ }^{46}$ Kate Millett, Sexual Politics (London: Rupert Hart-Davis, 1971), 194.

${ }^{47}$ Jocelyne, A. Scutt, Even in the Best of Homes: Violence in the Family (Victoria: McClough Publishing, 1990), 194.

${ }^{48}$ Susan Faludi, Backlash: The Undeclared War Against American Woman (New York: Crown Books, 1991), 356-358.
} 
husband's brand of defilement; she knows that in reinstating her connection with him she is asking for abasement. ${ }^{49}$

What is demonstrably clear is that the novel triangulates sexual politics by intermingling love, sex and violence, and creating an enmeshment between those three elements. Moreover, Ilana and Gideon are intended to be representative of masculine and feminine binarisms - the symbolic and parabolic ingredients are borne out by the structure of the narrative. ${ }^{50}$

The correspondence between the two reveals the violence perpetrated by Gideon. This is for instance how he reacted upon discovering Ilana's infidelity:

[Y]ou were overwhelmed with lunatic glee... you punched me until by a battering cross-examination you dragged out of me every detail, every jot and shudder, and without undressing me you fucked me standing up as though knifing me, and during and after you didn't stop interrogating me more and more and again you mounted me on the kitchen table and your teeth dug into my shoulder and you slapped me with the back of your hand, like punishing an unruly horse. $^{51}$

If this isn't shocking enough, in another disturbing scene, Gideon relates another of his assaults, which this time includes his small son Boaz:

And how I came home one night and found a green lighter, not mine, on the kitchen table and started to punch you and suddenly he appeared in the kitchen in his spaceman pyjamas and asked me quietly to stop because you were [16]weaker. When I said to him, 'get into bed,' and went on hitting you, he picked up a little potted cactus and threw it at me, and it hit me on the cheek and I let go of you and grabbed hold of him in a frenzy and beat his golden head

\footnotetext{
${ }^{49}$ Walter Goodman, “"Black Box” Explores the Crash of a Marriage', New York Times (22 April 1988), 36.

${ }^{50}$ Avraham Balaban, El halashon Vmimena: Lashon u-metziut bi-yetzirat Amos Oz [Towards Language and Beyond: Language and Reality in the Prose of Amos Oz] (Tel Aviv: Am Oved, 1988), 175.

${ }^{51}$ Amos Oz, Black Box, 163.
} 
over and over again against the wall. I had my pistol in my pocket and I could have fired at the two of you that night and then put a bullet in myself. ${ }^{52}$

Despite, but more particularly, because of Gideon's abuse, Ilana is compulsively drawn to her former husband and re-establishes their torturous association. The explicit link between Gideon's cruelty to Ilana and her love for him is made obvious by her attraction to his sadistic brand of contempt for her: 'I loved you not despite your cruelty; I loved the dragon itself... You have never had anything, and you will never have, besides your torture dungeons. Which my flesh longs for. Your tropical hell. ${ }^{53}$

Oddly, she asks, why, as long as she was content to remain in the marriage, despite the deplorable episodes of violence, did he abandon her? And although she speaks of their incurable love, it never manifests itself in the text. On the contrary, their 'relationship is not based on affinity between equals, and there is no room in it for mutual understanding or intimacy achieved through openness and empathy. ${ }^{54}$ In this context, Oz makes no attempt to explain why Ilana, a victim of domestic violence, several times driven to attempt suicide, seeks an emotional bond with her abuser.

To be sure, the novel through the various plot devices, unabashedly and surely implies that Ilana is indeed masochistic. This impression is further emphasized by the perverse pleasure Ilana takes in degrading herself before Gideon, grovelling at his feet like a submissive slave-girl: 'But you were and remain my husband. My Lord and Master. Forever. You are the lord of my hatred and... Ruler of my hair and my throat and the soles of my feet. Sovereign of my breasts my belly my private parts my womb. Like a slave girl I am in thrall to you... Alec, I'm still prepared to lick your boots as much as you like. I'll do anything you ask of me... I'll be your wife and your [17] servant.' ${ }^{55}$ Ilana's self hate and inexplicable yearning for humiliation is

\footnotetext{
52 Ibid., 66.

${ }^{53}$ Ibid., 65, 84 .

${ }^{54}$ Avraham Balaban, El halashon Vmimena, 162.

${ }^{55}$ Amos Oz, Black Box, 42-43, 5, 144.
} 
constantly reaffirmed and amplified through the author's focus on her present husband, Michel Sommo, who is gentle and kind - the antithesis of Gideon. ${ }^{56}$

The representation of violence against female protagonists in the $\mathrm{Oz}$ cannon encompasses within its prism manifold ventilations, and often, only becomes apparent as one scratches the surfaces of the author's works to examine the seemingly insignificant deportment, thoughts and observations of secondary characters. The reason is that masculine hostility is frequently veiled as innocuous ruminations by a male character. Rogers, in her feminist manifesto on literary representation, states this premise nicely when she writes: 'I include among the manifestations of misogyny in literature not only direct expressions of hatred, fear, or contempt of womankind, but such indirect expressions as misogynistic speeches by dramatic characters... and condemnations of one woman or type of woman which spread implicitly or explicitly, to the whole sex. ${ }^{57}$ And although the subtext of anger and aggression towards women to be discussed is often only alluded to, it does affirm the presence of the consistent theme of hostility towards women interwoven within the several sub-narratives.

Rami Rimon of the novel Elsewhere Perhaps is a young man frustrated by his girlfriend, Noga Harish, who refuses to acquiesce to his sexual desires. He ponders the reason for his failure and concludes that 'he must press harder than he has pressed so far. It is well known that women admire strength. "The more you beat them, the better they be," the proverb says. He curses his weakness. He certainly won't get anywhere by talking. ${ }^{58}$ Earlier, during a flirtatious interlude with Noga, he makes up his mind to 'conquer' her by force, but relents to her rebuffs. Still, in a chapter titled 'Force', we are told of his new-found determination to 'beat a new path to his friends heart, a simple, straightforward path. ${ }^{59}$ As a result, sometime later, while in Noga's room, he brutishly grabs hold of her, squeezing her ribs and kneading her breasts, so much so that he extracts a painful moan from the young woman. Undeterred by her [18]pleas to stop he persists, he is foiled from forcing himself on Noga by the

\footnotetext{
${ }^{56}$ Efraim Tzoref, Nof Haadam Besipurey Amos $O z$ [The Human Landscape in the Stories of Amos Oz] (Jerusalem: Tzur Ot, 1988), 125.

${ }^{57}$ Katherine M. Rogers, The Troublesome Helpmate: A History of Misogyny in Literature (Seattle: The University of Washington Press, 1966), xii-xiii.

${ }_{58}^{58}$ Amos Oz, Elsewhere Perhaps, 81.

${ }^{59}$ Ibid., 91.
} 
appearance of another Kibbutz member, Ezra Berger. Later, Rami muses, 'Women understand only one language, brute force. ${ }^{, 60}$

Another reference to violence towards women is made in A Perfect Peace through a crime committed by an eccentric character named Bolognesi. His crime: murdering his brother's fiancé by chopping her head off with an axe. Ezra Berger of Elsewhere Perhaps, whose motto is 'A plague on all women, ${ }^{61}$ discloses his revulsion for the opposite sex when he echoes a biblical pronouncement, "II find woman more bitter than death," the preacher said, and he knew what he was talking about. ${ }^{62}$ Another character, Mitya, of The Hill Of Evil Counsel speaks about doing harm to women:

[Y]our generation, whose souls have not been perverted by exile, have an obligation to make children by force by the women of the Fellahin. They wear long dark dresses down to their ankles, but underneath their dresses they have nothing on at all. They must be conquered and mounted by main force. With holy zeal... We must spill fresh blood, dark, warm blood. ${ }^{63}$ (my italics)

Whilst it is tempting to believe simplistically that these outbursts are inconsequent, they do exemplify the undercurrents of historically rooted misogynous codes of behaviour, interspersed within the stories - codes that reflect a litany of anti-woman rhetoric and attitudes. Sadly, the patriarchal legacy of violence that animates several of Oz's plots and which is inextricably enmeshed in the configuration of female subjugation, has been, for the most part, ignored by the Israeli literary establishment. As this essay sought to demonstrate, the female characters in the $\mathrm{Oz}$ corpus are enclosed in dogma-fettered wrappings that abstract them as the recto and verso of a limiting model of sexuality.

\section{[19] BIBLIOGRAPHY}

Arad, Miriam, 'Devil in the Kibbutz', Jerusalem Post Book Reviews (28 October 1966), 21.

\footnotetext{
${ }^{60}$ Ibid., 168.

${ }^{61}$ Ibid., 59.

${ }^{62}$ Ibid., 59.

${ }^{63}$ Amos Oz, The Hill of Evil Counsel, 37-8.
} 
Avishay, Mordechay, 'Yetzarim Vetanim' [Jackals and Desires], Maariv (11 June 1976), 1-3.

Balaban, Avraham, El halashon Vmimena: Lashon u-metziut bi-yetzirat Amos $\mathrm{Oz}$ [Towards Language and Beyond: Language and Reality in the Prose of Amos Oz] (Tel Aviv: Am Oved, 1988).

Bar On, Bat Ami, The Subject of Violence: Arendtean Exercises in Understanding (Lanham: Rowman \& Littlefield, 2002).

Bar On, Bat Ami, and Ann Ferguson, eds., Daring to be Good: Essays in Feminist Ethico-Politics (New York: Routledge, 1998).

Benstock, Shari, ed., Feminist Issues in Literary Scholarship (Bloomington: Indiana Press, 1987).

Brownstein, Rachel, Becoming a Heroine: Reading about Women in Novels (Harmondsworth: Penguin, 1982).

Elam, Diane, Romancing the Postmodern (London, New York: Routledge, 1992).

Elam, Diane, Feminism and Deconstruction: Ms. en Abyme (London, New York: Routledge, 1994).

Elam, Diane, and Robyn Wiegman, eds., Feminism Beside Itself (New York: Routledge, 1995).

Faludi, Susan, Backlash: The Undeclared War Against American Women (New York: Crown Books, 1991).

Fuchs, Esther, 'The Beast Within: Women in Amos Oz's Early Fiction', Modern Judaism 4:3 (1984), 311-321.

Goodman, Walter, “"Black Box” Explores the Crash of a Marriage', New York Times (22 April 1988), 36.

Greer, Germaine, Female Eunuch (London: Macgibbon \& Kee, 1970).

Hays, H.R., The Dangerous Sex: The Myth of Feminine Evil (New York: Putnam, 1964).

Levitt, Laura, Jews and Feminism: The Ambivalent Search for Home (New York: Routledge, 1997).

[20]Levitt, Laura and Miriam Peskowitz, eds., Judaism Since Gender (New York: Routledge, 1997).

Morris, Pam, Literature and Feminism (Oxford: Blackwell Publishers, 1993). 
Oren, Yosef, Tziyonut Vetzabariut Baroman Haisraeli [Zionism and Sabraism in the Israeli Novel] (Tel Aviv: Yachad Press, 1990).

Oz, Amos, Artzot Hatan [The Lands of the Jackals] (Tel Aviv: Masada, 1965).

Oz, Amos, Elsewhere Perhaps, trans. by Nicholas de Lange (Orlando: Harcourt Brace Jovanovich, 1973). Hebrew original 1966.

Oz, Amos, To Know A Woman, trans. by Nicholas de Lange (London: Vintagem 1992). Hebrew original 1989.

Oz, Amos, Where the Jackals Howl, trans. by Nicholas de Lange (London: Vintage, 1992). Hebrew original 1965.

Oz, Amos, A Perfect Peace, trans. by Nicholas de Lange (London: Vintage, 1993). Hebrew original 1982.

Oz, Amos, Black Box, trans. by Nicholas de Lange (London: Vintage, 1993). Hebrew original 1987.

Oz, Amos, The Hill of Evil Counsel, trans. by Nicholas de Lange (London: Vintage, 1993). Hebrew original 1976.

Ruthven, K.K., Feminist Literary Studies (Cambridge: Cambridge University Press, 1990).

Scutt, Jocelyne A., Even in the Best of Homes: Violence in the Family (Victoria: McClough Publishing, 1990).

Showalter, Elaine, ed., The New Feminist Criticism: Essays on Women, Literature and Theory (New York: Pantheon Books, 1985).

Showalter, Elaine, Sexual Anarchy: Gender and Culture at the Fin de Siècle (London: Bloomsbury, 1991).

Tzoref, Efraim, Nof Haadam Besipurey Amos Oz [The Human Landscape in the Stories of Amos $\mathrm{Oz}$ ] (Jerusalem: Tzur Ot, 1988).

Wachtel, Eleanor, 'Amos Oz', Queens Quarterly 98:2 (Summer, 1991), 424-431. 